\title{
Identification of a New Genotype of Fusarium oxysporum f. sp. vasinfectum on Cotton in China
}

\author{
Qinggang Guo, Shezeng Li, Xiuyun Lu, Hui Gao, and Xiaoguang Wang, Institute of Plant Protection, Hebei Academy of Agricultural and \\ Forestry Sciences; Integrated Pest Management Center of Hebei Province; Key Laboratory of IPM on Crops in Northern Region of North \\ China, Ministry of Agriculture, Baoding, 071000, China; Yinan Ma, School of Molecular and Biomedical Science, University of Adelaide, \\ Adelaide 5005, SA, Australia; and Xiaoyun Zhang, Peipei Wang, and Ping Ma, Institute of Plant Protection, Hebei Academy of Agricultural \\ and Forestry Sciences; Integrated Pest Management Center of Hebei Province; Key Laboratory of IPM on Crops in Northern Region of North \\ China, Ministry of Agriculture, Baoding, China
}

\begin{abstract}
Guo, Q., Li, S., Lu, X., Gao, H., Wang, X., Ma, Y., Zhang, X., Wang, P., and Ma, P. 2015. Identification of a new genotype of Fusarium oxysporum f. sp. vasinfectum on cotton in China. Plant Dis. 99:1569-1577.

Genetic composition of Fusarium oxysporum f. sp. vasinfectum strains, including race 3,7 , and 8 , Australian genotype strain, and 80 strains collected from China, were studied using amplified fragment length polymorphism (AFLP). Based on AFLP analysis, these strains were separated into four groups. Race 3, strain CN3, was the only strain in group A. Race 8, strain CN8, was the only strain in group B. Race 7, strain CN7, was grouped with 75 strains from China in group C. The Australian genotype strain ATCC96291 was grouped with five strains from China in group D. Evolution of the five native strains in group D

was studied using multigene genealogies. Phylogenetic tree analysis revealed that the five strains of group D had a closer genetic relationship to the Australian genotype strain than the other races based on the combined elongation factor, $\beta$-tubulin, and phosphate permase gene sequence data. Group D was further tested for pathogenicity and virulence on four cotton cultivars from Upland (Gossypium hirsutum) and Sea Island (G. barbadense) cotton. All five strains caused typical Fusarium wilt symptoms on all four cotton cultivars but virulence were relatively low compared with race 3 , race 7 , and race 8 .
\end{abstract}

Fusarium wilt of cotton, caused by Fusarium oxysporum f. sp. vasinfectum W. C. Snyder \& H. N. Hansen, is a serious, soilborne disease responsible for significant losses in yield and quality in China and other major cotton-producing areas of the world (Davis et al. 2006). Host-plant resistance has been identified as the most practical and cost-efficient strategy for long-term management of Fusarium wilt (Aguiar et al. 2013; Hall et al. 2013). The success of breeding resistant cultivars depends on a better understanding of the genetic structure and variation of the population of $F$. oxysporum f. sp. vasinfectum. Therefore, detailed knowledge of the genetic diversity and evolutionary relationships within $F$. oxysporum $\mathrm{f}$. sp. vasinfectum provides an important framework for breeding resistant cultivars (Skovgaard et al. 2001). Global genetic variation of $F$. oxysporum f. sp. vasinfectum has been intensively studied worldwide, and eight distinct races have been characterized based on pathogenicity testing on cotton (Gossypium spp.) and noncotton differential hosts. Races 1 and 2 were mainly described in the United States and Tanzania. Race 2 was distinguished from race 1 by its greater virulence on noncotton differential hosts and the production of aesculin (Bridge et al. 1993). Race 3 was described in Egypt, Sudan, Israel, and China (Davis et al. 2006). Race 4 was first described in India but, at present, it was thought to be the most virulent strain of $F$. oxysporum $\mathrm{f}$. sp. vasinfectum in California (Ulloa et al. 2013). Race 5 was initially described in Sudan and then withdrawn because its culture characteristics and virulence were identical to race 3 (Nirenberg et al. 1994). Race 6 was described in Brazil and Paraguay and had identical virulence with races 1 and 2 on cotton cultivars. However, race 6 could not cause

Corresponding author: P. Ma; E-mail: pingma88@126.com

*The $\boldsymbol{e}$-Xtra logo stands for "electronic extra" and indicates that one supplementary figure is published online.

Accepted for publication 27 April 2015.

http://dx.doi.org/10.1094/PDIS-12-14-1238-RE

(C) 2015 The American Phytopathological Society wilt on alfalfa, soybean, tobacco, or lupine, which are susceptible to races 1 and 2 (Armstrong and Armstrong 1978). Race 7 and race 8 were mainly described in China (Chen et al. 1985). Strains of race 7 were genetically indistinguishable from the race 4 strains from India. However, strains of races 4 and 7 can be separated by their pathogenicity toward differential hosts (Davis et al. 2006; Skovgaard et al. 2001). Since the late 1990s, a highly virulent population of $F$. oxysporum f. sp. vasinfectum has emerged in Australia. Australian strains of $F$. oxysporum f. sp. vasinfectum were shown to be genetically distinct from all known biotype, and were thought to have evolved from indigenous races (Wang et al. 2010). Originally, all the races had distinct geographical locations, but with the transnational transportation of cotton seed, the distribution of races has changed. For example, $F$. oxysporum f. sp. vasinfectum races 3, 4, and 8 have been cultured from a collection of isolates in California (Kim et al. 2005), and the Australian genotype strains also have been detected in imported, live cottonseed in California (Liu et al. 2011).

Pathogenicity tests are time consuming and require careful standardization of procedures, because different inoculation densities (Devay et al. 1997) and inoculation methods (Ibrahim and Nirenberg 1993) may change the pathogenic reactions for some cultivars. Therefore, the determination of some $F$. oxysporum $\mathrm{f}$. sp. vasinfectum races may be ambiguous if based only on pathogenic reactions on some cultivars (Davis et al. 2006). In recent years, DNA-based techniques have been used to provide a more reproducible and less labor-intensive method to help distinguish the races of $F$. oxysporum f. sp. vasinfectum (Abd-Elsalam et al. 2004; Assigbetse et al. 1994) and other formae speciales (Ellis et al. 2014; Fraser-Smith et al. 2014; Luongo et al. 2015). Amplified fragment length polymorphisms (AFLP) are effective and powerful markers to determine intraspecific genetic variation in fungi without prior knowledge of the genome information (Mueller and Wolfenbarger 1999). Recently, AFLP technology has been used to detect genetic variation among isolates of $F$. oxysporum f. sp. vasinfectum, and was useful in distinguishing the different races (Egamberdiev et al. 2013; Wang et al. 2006). In addition, multigene genealogy analysis has been conducted on DNA sequences encoding several predominately single-copy nuclear genes (e.g., elongation factor $[\mathrm{EF}-1 \alpha], \beta$-tubulin $[\mathrm{BT}]$, and 
phosphate permase [PHO]). These data have recently been used to study evolutionary relationships among closely related fungal species (Silva et al. 2014). With a phylogenetic analysis based on the combination of EF-1 $\alpha$, BT, and PHO, the known $F$. oxysporum f. sp. vasinfectum races could be sorted into four lineages. Lineage I contained races 3 and 5; lineage II contained races 1, 2, and 6; lineage III contained race 8 ; and lineage IV contained races 4 and 7 . The Australian genotypes formed a strongly supported independent lineage (Skovgaard et al. 2001).

Fusarium wilt was first discovered in 1934 in China, and caused significant losses to cotton production from 1970 to 1980. After the 1980s, Fusarium wilt was effectively controlled with the development of more resistant Upland cotton (Gossypium hirsutum) varieties (Ma et al. 2002). In recent years, Fusarium wilt has caused increasing damage in some cotton-growing regions. This may be partially attributed to changes in the genetic structure of the $F$. oxysporum f. sp. vasinfectum population in China. Therefore, a more comprehensive survey of this genetic structure is needed to accurately determine the diversity and locality of $F$. oxysporum $\mathrm{f}$. sp. vasinfectum strains in China. It is important to effectively breed and distribute resistant cultivars, and detailed knowledge of the genetic diversity and evolutionary relationships within $F$. oxysporum f. sp. vasinfectum will provide an important framework to do so. The primary objective of this study was to characterize the genotypes of $F$. oxysporum f. sp. vasinfectum strains on cotton in China using AFLP and gene sequencing.

\section{Materials and Methods}

Strains. Eighty new pathogenic strains of $F$. oxysporum $\mathrm{f}$. sp. vasinfectum were recovered from individual cotton-growing fields in China from 2007 to 2010 (Table 1). These strains were collected from diseased cotton plants diagnosed by the presence of symptoms of wilt and brown, discolored vessels in their stems (Abo et al. 2005). The strains were then purified from single spores. All purified strains were first detected with primer pair Fov1-Eg-f/Fov1-Eg-r (Abd-Elsalam et al. 2006) and then pathogenicity tests were conducted on Fusarium wilt-susceptible cotton Jimian 11. Reference strains CN3 (race 3), CN7 (race 7), and CN8 (race 8) were kept in our lab, and Australian F. oxysporum f. sp. vasinfectum type strain ATCC96291 was purchased from the American Type Culture Collection (ATCC).

DNA extraction. For DNA extraction from cultures, $F$. oxysporum f. sp. vasinfectum strains were grown in $100 \mathrm{ml}$ of potato dextrose

Table 1. Strains of Fusarium oxysporum f. sp. vasinfectum characterized in this study

\begin{tabular}{|c|c|c|c|c|}
\hline Strain & Virulence $^{\mathbf{a}}$ & Lineage $^{b}$ & Geographic origin & Source ${ }^{c}$ \\
\hline $\mathrm{CN} 3$ & Moderate & A & China & Sun et al. 1999 \\
\hline $\mathrm{CN} 8$ & Moderate & $\mathrm{B}$ & China & Sun et al. 1999 \\
\hline CN7 & Moderate & $\mathrm{C}$ & China & Sun et al. 1999 \\
\hline ATCC96291 & $\ldots$ & $\mathrm{D}$ & Australian & ATCC \\
\hline HB177 & High & $\mathrm{C}$ & Xianxian, Hebei & This study \\
\hline HB31 & High & $\mathrm{C}$ & Jingxian, Hebei & This study \\
\hline HB41 & High & $\mathrm{C}$ & Jingxian, Hebei & This study \\
\hline HB64 & High & $\mathrm{C}$ & Weixian, Hebei & This study \\
\hline HB67 & Moderate & $\mathrm{C}$ & Weixian, Hebei & This study \\
\hline HB68 & Moderate & $\mathrm{C}$ & Weixian, Hebei & This study \\
\hline HB78 & High & $\mathrm{C}$ & Weixian, Hebei & This study \\
\hline HB79 & High & $\mathrm{C}$ & Weixian, Hebei & This study \\
\hline HB152 & High & $\mathrm{C}$ & Weixian, Hebei & This study \\
\hline HB152-2 & High & $\mathrm{C}$ & Weixian, Hebei & This study \\
\hline HB88 & High & $\mathrm{C}$ & Qiuxian, Hebei & This study \\
\hline HB89 & High & $\mathrm{C}$ & Qiuxian, Hebei & This study \\
\hline HB1 & High & $\mathrm{C}$ & Gaoyang, Hebei & This study \\
\hline HB2 & High & $\mathrm{C}$ & Gaoyang, Hebei & This study \\
\hline HB54 & High & $\mathrm{C}$ & Nangong, Hebei & This study \\
\hline HB55 & High & $\mathrm{C}$ & Nangong, Hebei & This study \\
\hline HB57 & High & $\mathrm{C}$ & Nangong, Hebei & This study \\
\hline HB61 & High & $\mathrm{C}$ & Nangong, Hebei & This study \\
\hline HB90-3 & High & $\mathrm{C}$ & Quzhou, Hebei & This study \\
\hline HB93 & High & $\mathrm{C}$ & Quzhou, Hebei & This study \\
\hline HB146 & High & $\mathrm{C}$ & Quzhou, Hebei & This study \\
\hline HB147 & High & $\mathrm{C}$ & Quzhou, Hebei & This study \\
\hline HB98 & High & $\mathrm{C}$ & Guantao, Hebei & This study \\
\hline HB162 & High & $\mathrm{C}$ & Guantao, Hebei & This study \\
\hline HB 163 & High & $\mathrm{C}$ & Guantao, Hebei & This study \\
\hline HB163-2 & Moderate & $\mathrm{C}$ & Guantao, Hebei & This study \\
\hline HB13 & High & $\mathrm{C}$ & Nanpi, Hebei & This study \\
\hline HB17-2 & High & $\mathrm{C}$ & Dongguang, Hebei & This study \\
\hline HB18 & High & $\mathrm{C}$ & Dongguang, Hebei & This study \\
\hline HB20 & High & $\mathrm{C}$ & Fucheng, Hebei & This study \\
\hline HB21 & High & $\mathrm{C}$ & Fucheng, Hebei & This study \\
\hline HB22-2 & Moderate & $\mathrm{C}$ & Fucheng, Hebei & This study \\
\hline HB33 & Moderate & $\mathrm{C}$ & Wuqiao, Hebei & This study \\
\hline HB34 & Moderate & $\mathrm{C}$ & Wuqiao, Hebei & This study \\
\hline HB36-2 & High & $\mathrm{C}$ & Wuqiao, Hebei & This study \\
\hline \multirow[t]{2}{*}{ HB75 } & High & $\mathrm{C}$ & Linxi, Hebei & This study \\
\hline & Hign & $c$ & Linxi, Hebel & d on next page) \\
\hline
\end{tabular}

\footnotetext{
a Virulence was tested on the Fusarium wilt-sensitive cotton Jimian 11. The virulence level of $F$. oxysporum f. sp. vasinfectum was determined based on the disease index where $>50=$ highly virulent, 30 to $50=$ moderately virulent, and $<30=$ minimally virulent.

b Lineage was separated based on the amplified fragment length polymorphism analysis.

c Strains CN3, CN7, and CN8 were strains Ag78, Ag157, and Ag3, respectively, in Sun et al. (1999); ATCC = American Type Culture Collection.
} 
broth (PDB) in 250-ml Erlenmeyer flasks for 4 to 5 days at $24^{\circ} \mathrm{C}$, without shaking and in darkness. The mycelia were filtered from the PDB and washed three times with sterile, distilled water. Approximately $200 \mathrm{mg}$ of mycelium from each flask was ground into a powder using liquid nitrogen. Extraction of total genomic DNA was as described by Harvey et al. (2001), and further purified using a TaKaRa MiniBEST Universal Genomic DNA Extraction Kit (TaKaRa Biotech, Dalian, China). The concentration of genomic DNA was quantified by optical density measurements at $260 \mathrm{~nm}$ using a NanoDrop (Nanodrop Technologies, Wilmington, DE). DNA was stored at $-20^{\circ} \mathrm{C}$ prior to use.

Evaluation of primer combinations. A preliminary study was conducted with 48 primer combinations (HaeIII+C, CA, G, and $\mathrm{GA} / P s t \mathrm{I}+\mathrm{NN}$, where $\mathrm{N}=\mathrm{A}, \mathrm{T}, \mathrm{C}$, or $\mathrm{G}$ ) and eight $F$. oxysporum f. sp. vasinfectum reference strains (CN3, CN7, CN8, ATCC96291, and four strains collected from China) to identify the most polymorphic primer set for definitive analyses. The selected primer combinations were used for characterization of all $84 F$. oxysporum $\mathrm{f}$. sp. vasinfectum strains.

AFLP analysis. AFLP analysis was accomplished as described by Gomez et al. (2006) and Hazen et al. (2002). Briefly, $250 \mathrm{ng}$ of purified genomic DNA from each strain was digested with HaeIII and PstI (TaKaRa Biotech), and the resulting fragments were ligated to HaeIII and PstI double-stranded adapters (Invitrogen, Beijing). The ligated DNA samples were diluted 10 -fold, and $2 \mu 1$ of the diluted DNA was used for preamplification using HaeIII-0 and PstI-0 primers. The polymerase chain reaction (PCR) conditions consisted of the cycling profile of $94^{\circ} \mathrm{C}$ for $30 \mathrm{~s}, 56^{\circ} \mathrm{C}$ for $60 \mathrm{~s}$, and $72^{\circ} \mathrm{C}$ for $60 \mathrm{~s}$, repeated for 20 cycles. The reaction mixture was diluted 10 -fold, and $4 \mu \mathrm{l}$ was subsequently used for selective amplification of each of the 48 primer combinations. Selective amplifications were performed in $20-\mu 1$ reactions using a cycling profile of $94^{\circ} \mathrm{C}$ for $30 \mathrm{~s}, 65^{\circ} \mathrm{C}$ for $30 \mathrm{~s}$, and $72^{\circ} \mathrm{C}$ for $1 \mathrm{~min}$ for one cycle and then lowering the annealing temperature by $1{ }^{\circ} \mathrm{C}$ each cycle to $56^{\circ} \mathrm{C}(9$ cycles $)$, followed by an additional 23 cycles at the $56^{\circ} \mathrm{C}$ annealing temperature. AFLP products were run on a $6 \%$ denaturing polyacrylamide gel in $1 \times$ Trisborate-EDTA buffer at $60 \mathrm{~W}$ for $3 \mathrm{~h}$. The amplification products were visualized by silver staining according to Creste et al. (2001), and the gel was dried overnight before being recorded and photographed. The molecular mass of the fragments was determined by comparison with a 50-bp DNA marker. Each AFLP profile was repeated twice, and only consistent bands were recorded.

Table 1. (continued from preceding page)

\begin{tabular}{|c|c|c|c|c|}
\hline Strain & Virulence $^{\mathbf{a}}$ & Lineage $^{b}$ & Geographic origin & Source $^{c}$ \\
\hline HB76 & Low & $\mathrm{C}$ & Linxi, Hebei & This study \\
\hline HB95 & Low & $\mathrm{C}$ & Guangping, Hebei & This study \\
\hline HB95-2 & Moderate & $\mathrm{C}$ & Guangping, Hebei & This study \\
\hline HB4 & High & $\mathrm{C}$ & Hejian, Hebei & This study \\
\hline HB44 & High & $\mathrm{C}$ & Gucheng, Hebei & This study \\
\hline HB172 & High & $\mathrm{C}$ & Gucheng, Hebei & This study \\
\hline HB46 & High & $\mathrm{C}$ & Zaoqiang, Hebei & This study \\
\hline HB47 & High & $\mathrm{C}$ & Zaoqiang, Hebei & This study \\
\hline HB49 & High & $\mathrm{C}$ & Zaoqiang, Hebei & This study \\
\hline HB154 & High & $\mathrm{C}$ & Feixiang, Hebei & This study \\
\hline HB148 & Moderate & $\mathrm{C}$ & Jize, Hebei & This study \\
\hline HB157 & High & $\mathrm{C}$ & Jize, Hebei & This study \\
\hline HB108-3 & Low & $\mathrm{C}$ & Jize, Hebei & This study \\
\hline HB52 & Moderate & $\mathrm{C}$ & Jizhou, Hebei & This study \\
\hline HB40 & High & $\mathrm{C}$ & Yongnian, Hebei & This study \\
\hline HB110 & High & $\mathrm{C}$ & Pingxiang, Hebei & This study \\
\hline HB110-2 & High & $\mathrm{C}$ & Pingxiang, Hebei & This study \\
\hline HB179-2 & High & $\mathrm{C}$ & Hejian, Hebei & This study \\
\hline $\mathrm{HB} 120$ & Low & $\mathrm{C}$ & Xinhe, Hebei & This study \\
\hline $\mathrm{HB} 122$ & High & $\mathrm{C}$ & Xinhe, Hebei & This study \\
\hline HB124 & Moderate & $\mathrm{C}$ & Ningjin, Hebei & This study \\
\hline HB126 & High & $\mathrm{C}$ & Xinji, Hebei & This study \\
\hline HB180-2 & Low & $\mathrm{C}$ & Dingxing, Hebei & This study \\
\hline HB72 & Low & $\mathrm{C}$ & Qinghe, Hebei & This study \\
\hline HB73 & High & $\mathrm{C}$ & Qinghe, Hebei & This study \\
\hline HB183 & High & $\mathrm{C}$ & Baoding, Hebei & This study \\
\hline HB183-2 & High & $\mathrm{C}$ & Baoding, Hebei & This study \\
\hline HB184 & High & $\mathrm{C}$ & Fengnan, Hebei & This study \\
\hline HB185 & High & $\mathrm{C}$ & Fengnan, Hebei & This study \\
\hline HB185-2 & High & $\mathrm{C}$ & Fengnan, Hebei & This study \\
\hline HB351-2 & High & $\mathrm{C}$ & Fengnan, Hebei & This study \\
\hline HB351-1 & Moderate & $\mathrm{C}$ & Fengnan, Hebei & This study \\
\hline HB351 & High & $\mathrm{C}$ & Fengnan, Hebei & This study \\
\hline HBD & Moderate & $\mathrm{C}$ & Dongying, Shandong & This study \\
\hline HBD1 & Moderate & $\mathrm{C}$ & Dongying, Shandong & This study \\
\hline HBD2 & Moderate & $\mathrm{C}$ & Dongying, Shandong & This study \\
\hline HBD3 & Moderate & $\mathrm{C}$ & Dongying, Shandong & This study \\
\hline HBD4 & Moderate & $\mathrm{C}$ & Dongying, Shandong & This study \\
\hline HBA & Moderate & $\mathrm{C}$ & Akesu, Xinjiang & This study \\
\hline HB7 & Low & $\mathrm{D}$ & Xianxian, Hebei & This study \\
\hline HB8 & Low & $\mathrm{D}$ & Botou, Hebei & This study \\
\hline HB48 & Low & $\mathrm{D}$ & Zaoqiang, Hebei & This study \\
\hline HB70 & Low & $\mathrm{D}$ & Weixian, Hebei & This study \\
\hline HB114 & Low & $\mathrm{D}$ & Guangzong, Hebei & This study \\
\hline
\end{tabular}


Cluster analysis. Fragments between 50 and 500 bp were scored as present (1) or absent (0) to form a raw data matrix. Phylogenetic analysis was conducted using NTSYSpc 2.10 (Applied Biostatistics, Inc., Setauket, NY). Binary data from each primer pair were combined and pairwise genetic similarities among strains were calculated using the Dice coefficient (Nei 1978). The dendrogram tree displaying associations among strains was generated with the unweighted pair-group method with arithmetic means (UPGMA) method. Topological stability of the dendrogram was assessed via 1,000 bootstrap replications using WinBoot.

PCR amplification of three housekeeping genes. Fragments of three housekeeping genes of $F$. oxysporum $\mathrm{f}$. sp. vasinfectum, (EF-1 $\alpha$, PHO, and BT) were amplified with primers EF-1: 5'-ATGGGTAAG GAAGACAAGAC-3' and EF-2: 5'-GGAAGTACCAGTGATCA TGTT-3' for the EF-1 $\alpha$ gene; BT-3: 5'-CGTCTAGAGGTACCCA TACCGGCA-3' and BT-5: 5'-GCTCTAGACTGCTTTCTGGCA GACC-3' for the BT gene; and PHO-1: 5'-ATCTTCTGGCGTGTTAT CATG-3' and PHO-6: 5'-GATGTGGTTGTAAGCAAAGCCC-3' for the PHO gene (Kim et al. 2005). Amplification was carried out in $20-\mu$ l reactions containing $2 \mu \mathrm{l}$ of PCR buffer (10x), $0.25 \mathrm{mM}$ each dNTP, $20 \mathrm{pM}$ each primer, $2.5 \mathrm{U}$ of rTaq polymerase (TaKaRa Biotech) and approximately $10 \mathrm{ng}$ of DNA template. The cycling program started with an initial denaturation at $95^{\circ} \mathrm{C}$ for $5 \mathrm{~min}$; followed by 35 cycles of $45 \mathrm{~s}$ at $94^{\circ} \mathrm{C}, 45 \mathrm{~s}$ at $58^{\circ} \mathrm{C}$, and $1 \mathrm{~min}$ at $72^{\circ} \mathrm{C}$; with a final extension of $10 \mathrm{~min}$ at $72^{\circ} \mathrm{C}$. Amplification products were purified using TaKaRa MiniBEST DNA Fragment Purification Kit (TaKaRa Biotech) and cloned into $p E A S Y$-T3 vectors (TransGen Biotech, Beijing), following the manufacturer's instructions. Transformants were selected on LuriaBertani agar containing X-gal $(40 \mu \mathrm{g} / \mathrm{ml})$ and ampicillin $(100 \mu \mathrm{g} / \mathrm{ml})$, the recombinant plasmids were extracted with a TaKaRa MiniBEST Plasmid Purification Kit (TaKaRa Biotech), and the inserted fragments were sequenced in both directions using primers T7 and SP6.

Phylogenetic analysis. All of the sequences generated in this study have been deposited in GenBank (Table 2). The nucleotide sequences of EF-1 $\alpha$, PHO, and BT were aligned with Clustal X (version 1.8). The similarity and divergence values between the sequences were calculated with MegAlign (DNASTAR, Inc., Madison, WI). Phylogenetic analysis was performed with MEGA and phylogenetic trees were constructed by the neighbor-joining method with bootstrap values based on 1,000 replications. Genetic distances were estimated using Kimura's two-parameter model (Kimura 1980). In addition, maximum-parsimony trees were constructed for comparison of the consistence with the neighbor-joining trees.

Pathogenicity tests. Fusarium wilt-susceptible Jimian 11 (G. hir sutum) was selected to evaluate the pathogenicity and virulence of all indigenous $F$. oxysporum $\mathrm{f}$. sp. vasinfectum strains, including reference strains $\mathrm{CN} 3, \mathrm{CN} 7$, and $\mathrm{CN} 8$ and the 80 strains collected from the field. Then, Jimian 11 cotton, Jimian 169 (G. hirsutum, tolerant cultivar), Zhongzhimian 2 (G. hirsutum, resistant cultivar), and Sea Island cotton Pima 90 (G. barbadense, moderate resistant cultivar) were selected to assess the virulence of eight $F$. oxysporum $\mathrm{f}$. sp. vasinfectum strains plus a water control. The eight tested strains included three strains of a new genotype (HB70, HB48, and HB114), two strains belonging to race 7 (HB180-2 and HB120), and three reference strains (CN3, CN7, and CN8). For inoculums preparation, $F$. oxysporum $\mathrm{f}$. sp. vasinfectum conidial suspensions were prepared from 5-day-old cultures in PDB, filtered through four layers of cheesecloth, and diluted to $1 \times 10^{6}$ conidia $/ \mathrm{ml}$ with sterilized water. Cotton seed were planted in 48-cell rootrainer trays: each rootrainer tray consists of eight platic rootrainer books, and each book forms six cells. Cotton seed were surface sterilized and germinated. Two seeds were then sown in each cell containing $200 \mathrm{~g}$ of sterilized potting mix (soil, vermiculite, and fertilizer at volume ratio of 2:1:0.1), and 24 cells (one-half rootrainer tray) were planted with one cotton cultivar. Rootrainer trays were put into plastic plates and then incubated in growth chambers at 28 and $18^{\circ} \mathrm{C}$ and $95 \%$ relative humidity, under a photoperiod of $16 \mathrm{~h}$ of light and $8 \mathrm{~h}$ of darkness. Two weeks later, roots of the cotton seedlings within the rootrainer tray were dipped in the conidial suspension for $30 \mathrm{~min}$, and then continued to be cultivated in growth chamber at 28 and $18^{\circ} \mathrm{C}$ and $95 \%$ relative humidity, under a photoperiod of $16 \mathrm{~h}$ of light and $8 \mathrm{~h}$ of darkness. Disease severity was measured approximately 4 to 5 weeks after inoculation. Individual plants were rated for disease severity based on the following scale: $0=$ no symptoms, $1=$ chlorosis or wilt restricted to cotyledons or first leaf, $2=$ similar symptoms extended beyond the first leaf, 3 = severe symptoms with the whole plant

Table 2. GenBank accession numbers of Fusarium oxysporum f. sp. vasinfectum strains used for evolutionary analysis in this study

\begin{tabular}{|c|c|c|c|c|c|}
\hline \multirow[b]{2}{*}{ Strain } & \multirow[b]{2}{*}{ Origin } & \multirow[b]{2}{*}{ Lineage $^{\mathbf{a}}$} & \multicolumn{3}{|c|}{ GenBank accession number } \\
\hline & & & EF-1a & PHO & BT \\
\hline ATCC16421, race 1 & South Carolina & II & JF267540.1 & JF267573.1 & JF267598.1 \\
\hline ATCC 46644, race 1 & California & II & JF267541.1 & JF267574.1 & JF267599.1 \\
\hline ATCC 16611 , race 2 & United States & II & EU246547.1 & EU246665.1 & AY714091.1 \\
\hline $\mathrm{CA} 3$, race 3 & California & IV & AY714102.1 & AY714113.1 & AY714088.1 \\
\hline ATCC 16612 , race 3 & Egypt & IV & AY714106.2 & AY714120.1 & AY714092.1 \\
\hline CA14, race 4 & California & I & JF267549 & AY714116 & AY714086 \\
\hline ATCC 16613 , race 4 & India & I & JF267548 & AY714121 & AY714093 \\
\hline ATCC 36198 , race 6 & Brazil & II & JF267543 & AY714117 & AY714089 \\
\hline CA1, race 8 & California & III & JF267546 & AY714112 & AY714087 \\
\hline ATCC 31665 , race 8 & China & III & AY714108 & AY714123 & AY714095 \\
\hline Aust 16, Aus Type & Australia & $\mathrm{V}$ & AY714096 & AY714110 & AY714082 \\
\hline Aust 19, Aus Type & Australia & $\mathrm{V}$ & AY714097 & AY714111 & AY714083 \\
\hline $\mathrm{CN} 3$, race 3 & China & IV & KP192925 & KP175351 & KP175340 \\
\hline $\mathrm{CN} 7$, race 7 & China & I & KP192916 & KP175342 & KP195331 \\
\hline $\mathrm{CN} 8$, race 8 & China & III & KP192915 & KP175341 & KP175330 \\
\hline ATCC96291, Aus Type & Australian & $\mathrm{V}$ & KP212130 & KP212131 & KP212129 \\
\hline HB7 & Hebei & $\mathrm{V}$ & KP192917 & KP175343 & KP175332 \\
\hline HB8-2 & Hebei & $\mathrm{V}$ & KP192918 & KP175344 & KP175333 \\
\hline HB48 & Hebei & $\mathrm{V}$ & KP192919 & KP175345 & KP175334 \\
\hline HB70 & Hebei & $\mathrm{V}$ & KP192920 & KP175346 & KP175335 \\
\hline HB114 & Hebei & $\mathrm{V}$ & KP192921 & KP175347 & KP175336 \\
\hline HB120 & Hebei & I & KP192922 & KP175348 & KP175337 \\
\hline HB180-2 & Hebei & I & KP192923 & KP175349 & KP175338 \\
\hline Fo 1502 & $\ldots$ & Outgroup & AY714109 & AY714122 & AY714094 \\
\hline
\end{tabular}

\footnotetext{
${ }^{a}$ Lineage was separated based on the phylogenetic tree that was built with the multigene genealogies translational elongation factor (EF-1 $\left.\alpha\right), \beta$-tubulin $(\mathrm{BT})$, and
} phosphate permase (PHO) gene sequences. 
affected, and $4=$ plant dead. The disease index was calculated using the following formula: disease index $=\left[\sum(\right.$ scale $\times$ corresponding cotton number $) /($ maximal scale $\times$ total of cotton number $)] \times 100$. The virulence of $F$. oxysporum $\mathrm{f}$. sp. vasinfectum was determined based on the disease index, where $>50=$ highly virulent, 30 to $50=$ moderately virulent, and $<30=$ minimally virulent. For each individual cotton cultivar, 144 plants ( 48 plants $\times 3$ repeats) were used for each strain and using a random block design. Two independent trials were conducted to test the virulence of strains on the four cotton cultivars. Data were analyzed by one-way analysis of variance using SAS for Windows (ver. 9.0; SAS Institute Inc., Cary, NC). Differences were considered to be significant at a 95\% (or higher) confidence level.

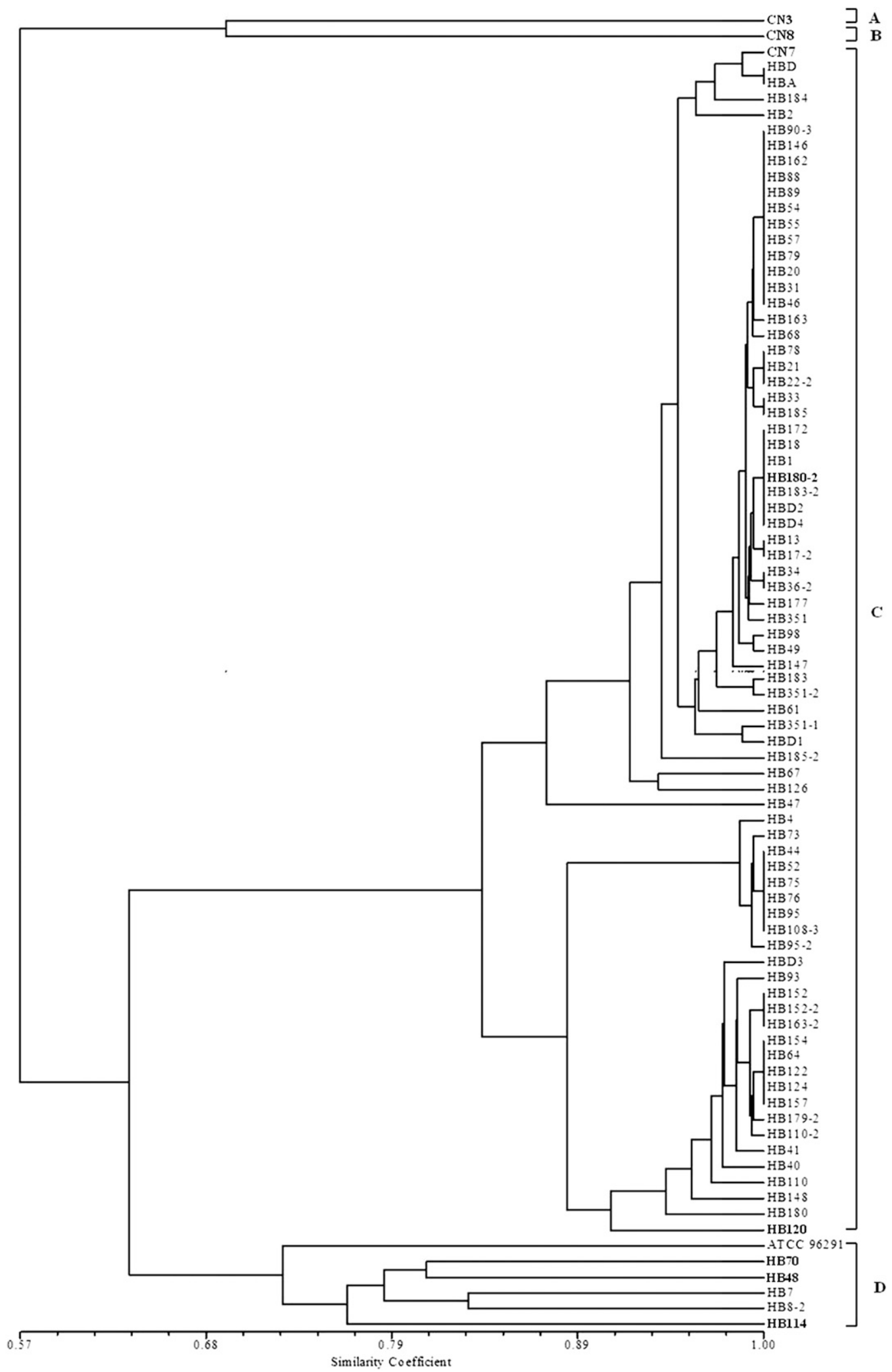

Fig. 1. Dendrogram generated using the amplified fragment length polymorphism dataset for the 84 Fusarium oxysporum f. sp. vasinfectum strains. Bootstrap values of $50 \%$ or more are indicated above nodes. 
The column plots were built with software Origin 7.0 (OriginLab Corporation, Northampton, MA).

\section{Results}

Pathogenicity test. Amplification of all 80 strains isolated from diseased cotton with primer pair Fov1-Eg-f/Fov1-Eg-r yielded a fragment of the expected size (data not shown). The 80 isolated strains and $F$. oxysporum f. sp. vasinfectum reference strains $\mathrm{CN} 3, \mathrm{CN} 7$, and $\mathrm{CN} 8$ were tested for pathogenicity and virulence on Fusarium wilt-susceptible Jimian 11 cotton in the greenhouse. Results indicated that all of these strains could cause typical Fusarium wilt symptoms on Jimian 11, including cotyledon drop, leaf chlorosis and necrosis, plant wilt, and sometimes death. However, the virulence was significantly different among the 83 tested strains: 52 strains showed high virulence, 20 strains showed moderate virulence, and 11 strains showed low virulence (Table 1).

Phylogenetic analysis of $F$. oxysporum f. sp. vasinfectum strains by AFLP. Phylogenetic analysis of the strains of $F$. oxysporum f. sp. vasinfectum was carried out using AFLP. By screening primer combinations in preliminary experiments, six primer sets (Hae IIII+C/PstI+TT, Hae III +G/Pst $\mathrm{I}+\mathrm{AC}$, Hae IIII+G/PstI+AG, Hae III+ $\mathrm{CA} / P s t \mathrm{I}+\mathrm{AA}, H a e \mathrm{III}+\mathrm{CA} / P s t \mathrm{I}+\mathrm{AT}$, and HaeIII+CA/PstI+TG) were selected from 48 primer combinations for their reliable and polymorphic banding patterns. In total, 476 unambiguous bands were amplified using the six selective primer combinations, of which 165 bands (35\%) were polymorphic. With the AFLP markers, reference strains CN3, CN7, and CN8 and Australian reference strain ATCC96291 could be unambiguously distinguished. Based on AFLP analysis, similarities between the $F$. oxysporum $\mathrm{f}$. sp. vasinfectum strains isolated from China ranged from 76 to $100 \%$. A dendrogram of the AFLP primer combinations separated the tested strains into four main groups (A to D) at $73 \%$ similarity level. Group A contained $\mathrm{CN} 3$, group $\mathrm{B}$ contained $\mathrm{CN} 8$, group $\mathrm{C}$ contained $\mathrm{CN} 7$ and 74 strains

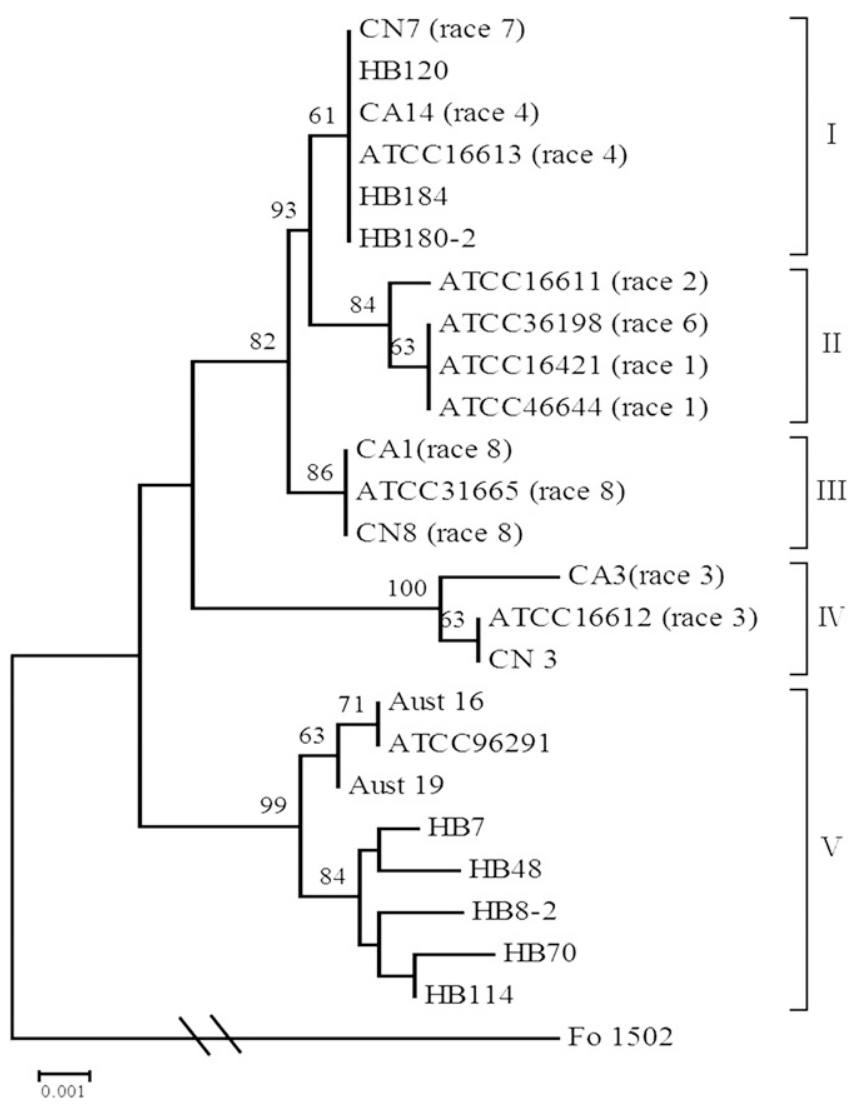

Fig. 2. Neighbor-joining tree generated from analysis of multigene genealogies translational elongation factor, $\beta$-tubulin, and phosphate permase gene sequences. Bootstrap frequencies from 1,000 replications are noted above the branches. isolated from China, and group D contained ATCC96291 and five strains isolated from China (Fig. 1). Group C was further divided into two well-supported subgroups, subgroup C-1 and subgroup C-2, with $87 \%$ similarity. Subgroup C-1 included CN7 plus 48 strains from China, and subgroup C-2 contained 27 strains from China.

Phylogenetic analysis of $F$. oxysporum f. sp. vasinfectum strains based on multigene genealogies. Race 3 , race 7 , and race 8 have been reported in China, but not the Australian genotype strains. Therefore, the five Chinese strains that clustered together with Australian reference strain ATCC96291 were temporarily named as new genotype strains HB7, HB8-2, HB70, HB48, and HB114 in this study. Additionally, two strains that clustered as subgroup C-2 in the AFLP phylogenetic tree, named HB180-2 and HB120, were collected together for further phylogenetic analysis. Phylogenetic analysis was conducted by amplification of three genes (EF-1 $\alpha$, BT, and PHO) from CN3, CN7, CN8, ATCC96291, HB180-2, HB120, and the five new genotype strains. Obtained sequences were 633 nucleotides for EF-1 $1 \alpha, 406$ nucleotides for BT, and 510 nucleotides for PHO. The three gene sequences from each test strain were then combined, and the concatenated sequences of three genes (EF-1 $\alpha, \mathrm{BT}$, and PHO) - in total, 1,549 bp-were compared with the sequences for races 1 to 8 and Australian genotypes obtained from GenBank (Table 2). The phylogenetic tree was constructed based on the combined gene sequences. The tree resolved the $F$. oxysporum f. sp. vasinfectum strains as five distinct lineages (I to V). Lineage I (61\% bootstrap) contained CN7 (race 7) from China, race 4 from India and the United States, and strains HB180-2 and HB120 from China, which were clustered as subgroup C-2 in the AFLP phylogenetic tree. Lineage II ( $84 \%$ bootstrap) included races 1 and 2 , which are primarily from the United States, and race 6 from Brazil. Lineage III ( $86 \%$ bootstrap) contained CN8 (race 8) from China. Lineage IV (100\% bootstrap) contained race 3 from China, Egypt, and the United States. Lineage V (99\% bootstrap) contained the three Australian genotype strains and the five strains from the new Chinese genotype. In lineage V, the Australian genotype strains and the five new Chinese genotype strains could be unambiguously divided into two sublineages: the three Australian reference strains composed one sublineage, and all five strains from China composed a second sublineage. With the combined DNA sequences, race 4 and race 7 in lineage I and race 1 , race 2 , and race 6 in lineage II could not be clearly differentiated (Fig. 2).

Pathogenic evaluation on different cotton cultivars. $F$. oxysporum f. sp. vasinfectum strains $\mathrm{CN} 3, \mathrm{CN} 7, \mathrm{CN} 8, \mathrm{HB} 70, \mathrm{HB} 48$, HB114, HB180-2, and HB120 were selected for the pathogenicity and virulence tests on four cotton cultivars. These cultivars included Jimian 11, Jimian 169, Zhongzhimian 2, and one Pima cultivar, Pima 90. All eight strains caused the typical symptoms of Fusarium wilt on the inoculated cultivars. The pathogens were recovered from the diseased plants and identified using their EF- $1 \alpha$ sequence. The EF- $1 \alpha$ sequencing showed that all reisolated strains were identical to the original inocula (data not shown), and no Fusarium sp. was recovered from noninoculated plants. All eight strains used in this study caused light symptoms on the resistant Pima 90 and the tolerant Jimian 169, with a disease index less than 30 , and no significant difference in virulence was observed among the tested strains. However, when evaluated on Fusarium wilt-susceptible Jimian 11 and resistant Zhongzhimian 2, the three new Chinese genotype strains HB70, HB48, and HB114 caused a significantly lower disease index on both cotton cultivars compared with reference strains $\mathrm{CN} 3, \mathrm{CN} 7$, and $\mathrm{CN} 8$, and had a comparatively lower disease index than the fieldcollected strains HB180-2 and HB120 (Fig. 3).

\section{Discussion}

Introduction of exogenous races of cotton pathogens may cause serious economic losses to local production. For example, race 4 was originally described in India in 1960 and in California in 2001; this strain was highly virulent to California cotton cultivars, causing serious losses to cotton production (Bennett et al. 2011). Therefore, it is necessary to constantly monitor the genetic structure 
of the local F. oxysporum f. sp. vasinfectum population. DNA-based techniques have been employed in conjunction with pathogenicity tests to distinguish the various races of $F$. oxysporum (Mishra et al. 2013). These tests were necessary when differential hosts were not available or pathogenicity tests of foreign strains under field or greenhouse conditions were not allowed under quarantine regulations. In this study, we used AFLP, which has the advantage of sampling loci throughout the entire pathogen genome. AFLP also provides powerful DNA fingerprinting for any organism (Mueller and Wolfenbarger 1999). Based on the AFLP analysis, the strains tested in this study were clearly separated into four groups: race 3 , race 7 , race 8 , and the Australian genotype strain. Most of the strains collected from China were grouped with race 7 , and race 7 was further divided into two subgroups with a Dice coefficient of 0.83 (subgroup C-1, containing race 7 , and subgroup $\mathrm{C}-2$ ). Therefore, results indicated that the physiological race 7 was the predominant race in China; however, the population genetics structure was diverse. In addition, virulence of the race 7 strains was different on the susceptible cotton Jimian 11, and the disease index ranged from 24 to 91 . Therefore, we suspected that the genetic structure of $F$. oxysporum $\mathrm{f}$. sp. vasinfectum in China might have changed in recent years, and this genetic variance included a point mutation or small insertion or deletion in some pathogenesis-associated genes in the $F$. oxysporum f. sp. vasinfectum genome.

Based on the pathogenicity tests using differential hosts, Sun et al. (1999) divided $84 F$. oxysporum $\mathrm{f}$. sp. vasinfectum strains from China into race 3 , race 7 , and race 8 , with race 7 being the predominant strain in China at that time. Strains $\mathrm{CN} 3, \mathrm{CN} 7$, and CN8 were comparable with strains $\mathrm{Ag} 78, \mathrm{Ag} 157$, and $\mathrm{Ag} 3$, respectively, by Sun et al. (1999). In our study, the virulence of strains CN3 and CN7 was identical to strains $\mathrm{Ag} 78$ and $\mathrm{Ag} 157$. However, strain CN8 showed a moderate virulence in our study but a low virulence in the reference of Sun et al. (1999). The virulence difference between CN8 and AG3 may be caused by the cultivars' resistance. Race 7 was still the predominant genotype in our study but a new genotype of $F$. oxysporum f. sp. vasinfectum clustered together with the Australian genotype strain based on the AFLP phylogenetic tree was discovered. To our knowledge, this is the first report of a new $F$. oxysporum $\mathrm{f}$. sp. vasinfectum genotype in China other than races 3,7 , and 8 . Because some races with different genetic backgrounds could not be separated based only on the pathogenicity test, we could not confirm whether or not the new genotype strains emerged recently. The sample sites of the strains used in our study have been recorded by GPS, all of the five new genotype strains were isolated from south of Hebei Province (Supplementary Fig. S1), and the distance of the sample sites between the new genotype strains ranged from 20.6 to $80.5 \mathrm{~km}$. In future research, we will isolate additional strains $F$. oxysporum $\mathrm{f}$. sp. vasinfectum from a wider region, and clarify the distribution of the new genotype.

DNA sequences of single-copy nuclear genes have recently been successfully used to study evolutionary relationships among the F. oxysporum f. sp. vasinfectum races (Liu et al. 2011). Based on
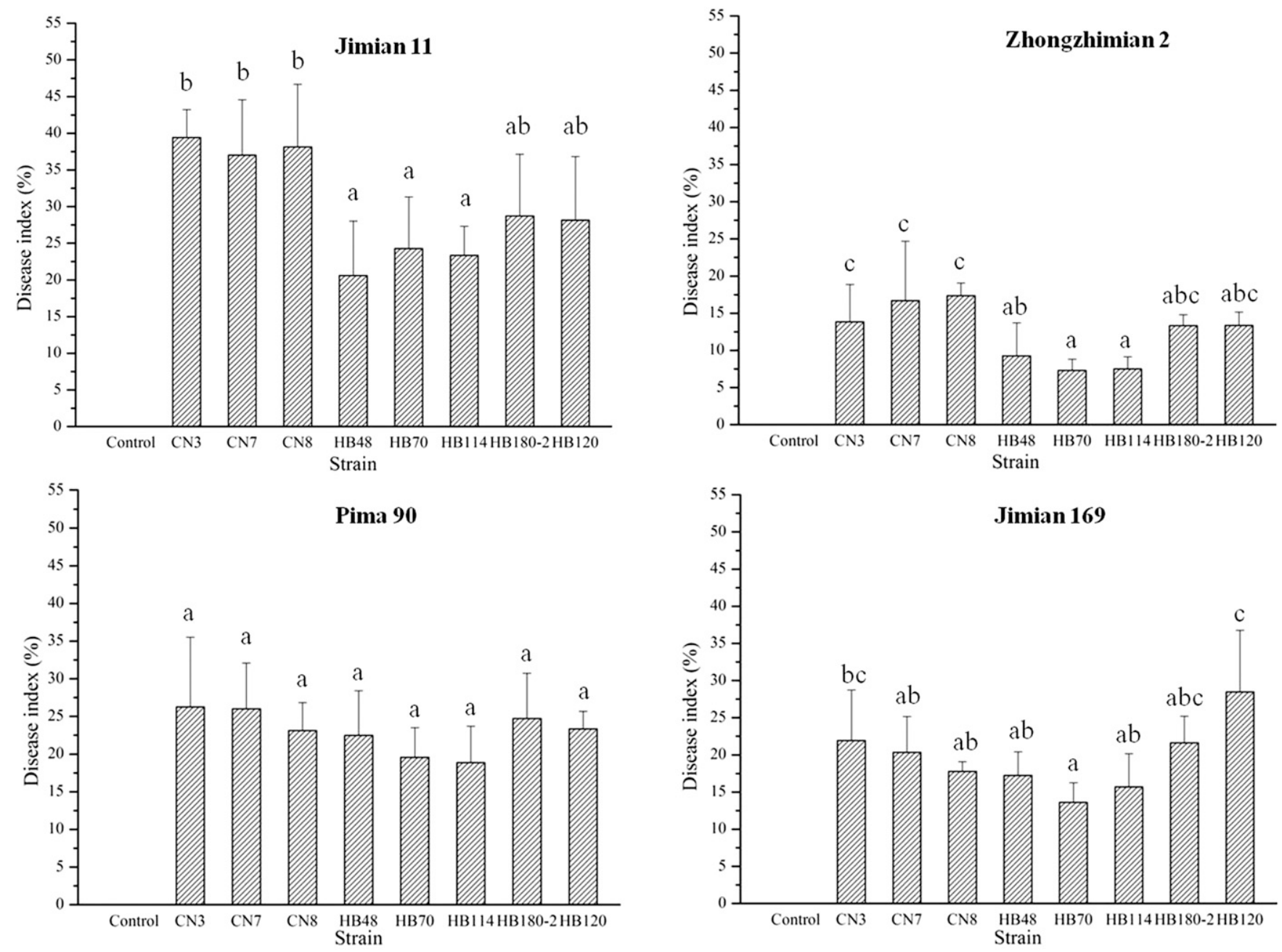

Fig. 3. Pathogenicity and virulence of Fusarium oxysporum f. sp. vasinfectum on selected cotton cultivars. Disease severity ratings were made 28 days after inoculation using a scale based on external symptoms: $0=$ no symptoms, $1=$ chlorosis or wilt restricted to cotyledons or the first leaf, $2=$ similar present above the first leaf, $3=$ severe symptoms with the whole plant affected, and $4=$ plant death. The disease index was calculated by the formula: Disease index $=\left[\sum\right.$ (scale $\times$ corresponding diseased plant number $) /($ maximal scale $\times$ total of plant number) $] \times 100$. Values are means of two replications. Significant differences were compared between tested strains and means with the same lowercase letter among treatments within a given cultivar are not significantly different $(P=0.05)$. 
the phylogenic tree inferred from combined analyses of EF-1 $1 \alpha$, nitrate reductase, and PHO gene sequences, the global genotypes of $F$. oxysporum f. sp. vasinfectum strains could be clearly separated as distinct lineages (Egamberdiev et al. 2013; Holmes et al. 2009; Silva et al. 2014). In this study, the strains with the new Chinese genotype revealed by AFLP analysis were further characterized by $\mathrm{EF}-1 \alpha, \mathrm{BT}$, and PHO gene sequences. The neighbor-joining tree generated from combined analysis of EF- $1 \alpha, \mathrm{BT}$, and PHO gene sequences revealed that the new Chinese genotype strains, as well as $F$. oxysporum f. sp. vasinfectum type strains whose gene sequences were directly obtained from GenBank, could be separated into five lineages. Lineage I contains races 4 and 7; lineage II contains races 1, 2, and 6; lineage III contains races 3 and 5; lineage IV contains race 8; and lineage $\mathrm{V}$ contains Australian genotypes and the new genotype strains isolated from China. Therefore, the five new genotype strains had a closer relationship to the Australian genotype than to the previously known races. We also noted from the phylogenetic tree, based on the multigene sequences, that lineage $\mathrm{V}$ was further divided into two subclades. The five new Chinese genotype strains clustered into one subclade, while the Australian genotype strains clustered into the other subclade. Therefore, we speculated that the new genotype strains were genetically similar only to the Australian genotype strain. This speculation was confirmed by the amplification results of genomic DNA from the five new Chinese genotype strains with Australian genotype strain-specific primers (Chakrabarti et al. 2011; Zambounis et al. 2007). The amplification signals were low when using DNA of the five new genotype strains as a template. The amplification signal was strong, however, when using the Australian strain ATCC96291 genomic DNA as a template (data not shown).

Fusarium wilt was first confirmed in 1993 in Australia and caused extensive seedling disease in heavy, neutral to alkaline soils even without the existence of nematodes (Hall et al. 2013). Based on multigene phylogenetic analysis, Wang et al. (2010) concluded that the Australian $F$. oxysporum f. sp. vasinfectum genotypes originated from native $F$. oxysporum strains in cotton-growing regions, and was clearly different from races 1 to 8 found in other countries. Initially, these genotypes existed only in Australia but, with the rapid development of international commerce, the Australian genotype had been reported outside of Australia. A large amount of cottonseed is imported into China from Australia annually; therefore, it is possible that the new genotype isolates closely related to the Australian biotype were brought into China with cottonseed. Sequence comparison of the entire genome could provide detailed information about the characteristic difference between closely related races. Therefore, in future work, we will conduct a whole-genome sequencing project for the new Chinese genotype strains and the Australian genotype strain to provide important information regarding the evolutionary relationship between the two genotypes.

F. oxysporum f. sp. vasinfectum in Australia was highly virulent on G. hirsutum and G. barbadense and no suitably resistant cultivar had been bred against Fusarium wilt in Australia to date. In this study, the new genotype strains isolated in China were less virulent on the three Upland cultivars and one Sea Island cultivar when compared with strains from races 3,7 , and 8 . These results may be because the cultivars used in this study were more resistant to strains of the new genotype, or the environmental conditions (e.g., soil properties and culture temperature) or evaluation methods may have affected the results of pathogenicity testing. Although the virulence of the new genotype strains was low in the present study, it may be enhanced by evolution under the selective pressure of the resistant cotton cultivars. Therefore, pathogenesis of the new genotype strains on different cultivars and in different soils should be monitored continuously.

\section{Acknowledgments}

This work was funded by the earmarked fund for China Agriculture Research System (CARS-18-15) and the National High Technology Research and Development Program ("863" Program) of China (2011AA10A205). We thank G. Jian in the Chinese Academy of Agricultural Sciences for providing the F. oxysporum f. sp. vasinfectum reference strains.

\section{Literature Cited}

Abd-Elsalam, K., Asran-Amal, A., Schnieder, F., Migheli, Q., and Verreet, J. A. 2006. Molecular detection of Fusarium oxysporum f. sp. vasinfectum in cotton roots by PCR and real-time PCR assay. J. Plant Dis. Prot. 113:S14-S19.

Abd-Elsalam, K. A., Omar, M. R., Migheli, Q., and Nirenberg, H. I. 2004. Genetic characterization of Fusarium oxysporum f. sp. vasinfectum isolates by random amplification of polymorphic DNA (RAPD) and amplified fragment length polymorphism (AFLP). J. Plant Dis. Prot. 111:534-544.

Abo, K., Klein, K. K., Edel-Hermann, V., Gautheron, N., Traore, D., and Steinberg, C. 2005. High genetic diversity among strains of Fusarium oxysporum f. sp. vasinfectum from cotton in Ivory Coast. Phytopathology 95:1391-1396.

Aguiar, F. M., Michereff, S. J., Boiteux, L. S., and Reis, A. 2013. Search for sources of resistance to Fusarium wilt (Fusarium oxysporum f. sp. vasinfectum) in okra germplasm. Crop Breed. Appl. Biot. 13:33-40.

Armstrong, G., and Armstrong, J. 1978. A new race (race 6) of the cotton-wilt Fusarium from Brazil. Plant Dis. Rep. 62:421-423.

Assigbetse, K., Fernandez, D., Dubois, M. P., and Geiger, J. P. 1994. Differentiation of Fusarium oxysporum f. sp. vasinfectum races on cotton by random amplified polymorphic DNA (RAPD) analysis. Phytopathology 84: 622-626.

Bennett, R. S., Spurgeon, D. W., Detar, W. R., Hutmacher, R. B., and Hanson, B. D. 2011. Efficacy of four soil treatments against Fusarium oxysporum f. sp. vasinfectum race 4 on cotton. Plant Dis. 95:967-976.

Bridge, P. D., Ismail, M., and Rutherford, M. 1993. An assessment of aesculin hydrolysis, vegetative compatibility and DNA polymorphism as criteria for characterizing pathogenic races within Fusarium oxysporum f. sp. vasinfectum. Plant Pathol. 42:264-269.

Chakrabarti, A., Rep, M., Wang, B., Ashton, A., Dodds, P., and Ellis, J. 2011. Variation in potential effector genes distinguishing Australian and nonAustralian isolates of the cotton wilt pathogen Fusarium oxysporum f. sp. vasinfectum. Plant Pathol. 60:232-243.

Chen, Q., Ji, X., and Sun, W. 1985. Identification of races of cotton wilt Fusarium in China. J. Agric. Sci. 6:1-6.

Creste, S., Neto, A. T., and Figueira, A. 2001. Detection of single sequence repeat polymorphisms in denaturing polyacrylamide sequencing gels by silver staining. Plant Mol. Biol. Rep. 19:299-306.

Davis, R. M., Colyer, P. D., Rothrock, C. S., and Kochman, J. K. 2006. Fusarium wilt of cotton: Population diversity and implications for management. Plant Dis. 90:692-703.

Devay, J. E., Gutierrez, A. P., Pullman, G. S., Wakeman, R. J., Garber, R. H., Jeffers, D. P., Smith, S. N., Goodell, P. B., and Roberts, P. A. 1997. Inoculum densities of Fusarium oxysporum f. sp. vasinfectum and Meloidogyne incognita in relation to the development of Fusarium wilt and the phenology of cotton plants (Gossypium hirsutum). Phytopathology 87:341-346.

Egamberdiev, S. S., Ulloa, M., Saha, S., Salakhutdinov, I. B., Abdullaev, A., Glukhova, L. A., Adylova, A. T., Scheffler, B. E., Jenkins, J. N., and Abdurakhmonov, I. Y. 2013. Molecular characterization of Uzbekistan isolates of Fusarium oxysporum f. sp. vasinfectum. J. Plant Sci. Mol. Breed. Online publication. doi:10.7243/2050-2389-2-3

Ellis, M. L., Jimenez, D. R., Leandro, L. F., and Munkvold, G. P. 2014. Genotypic and phenotypic characterization of fungi in the Fusarium oxysporum species complex from soybean roots. Phytopathology 104:1329-1339.

Fraser-Smith, S., Czislowski, E., Meldrum, R. A., Zander, M., O’Neill, W., Balali, G. R., and Aitken, E. A. B. 2014. Sequence variation in the putative effector gene SIX8 facilitates molecular differentiation of Fusarium oxysporum f. sp. cubense. Plant Pathol. 63:1044-1052.

Gomez, D. R., Evans, K. J., Harvey, P. R., Baker, J., Barton, J., Jourdan, M., Morin, L., Pennycook, S. R., and Scott, E. S. 2006. Genetic diversity in the blackberry rust pathogen, Phragmidium violaceum, in Europe and Australasia as revealed by analysis of SAMPL. Mycol. Res. 110:423-430.

Hall, C., Heath, R., and Guest, D. 2013. The infection process of Fusarium oxysporum f. sp. vasinfectum in Australian cotton. Australas. Plant Pathol. 42:1-8.

Harvey, P. R., Butterworth, P. J., Hawke, B. G., and Pankhurst, C. E. 2001. Genetic and pathogenic variation among cereal, medic and sub-clover isolates of Pythium irregulare. Mycol. Res. 105:85-93.

Hazen, S. P., Leroy, P., and Ward, R. W. 2002. AFLP in Triticum aestivum L.: Patterns of genetic diversity and genome distribution. Euphytica 125: 89-102.

Holmes, E. A., Bennett, R. S., Spurgeon, D. W., Colyer, P. D., and Davis, R. M. 2009. New genotypes of Fusarium oxysporum f. sp. vasinfectum from the southeastern United States. Plant Dis. 93:1298-1304.

Ibrahim, G., and Nirenberg, H. 1993. Response of some Sudanese cotton cultivars to race 1 and 5 of Fusarium oxysporum f. sp. vasinfectum. J. Plant Dis. Prot. 100:645-651.

Kim, Y., Hutmacher, R. B., and Davis, R. M. 2005. Characterization of California isolates of Fusarium oxysporum f. sp. vasinfectum. Plant Dis. 89:366-372.

Kimura, M. 1980. A simple method for estimating evolutionary rates of base substitutions through comparative studies of nucleotide sequences. J. Mol. Evol. 16:111-120.

Liu, J. G., Bell, A. A., Wheeler, M. H., Stipanovic, R. D., and Puckhaber, L. S. 2011. Phylogeny and pathogenicity of Fusarium oxysporum isolates from 
cottonseed imported from Australia into California for dairy cattle feed. Can. J. Microbiol. 57:874-886.

Luongo, L., Ferrarini, A., Haegi, A., Vitale, S., Polverari, A., and Belisario, A. 2015. Genetic diversity and pathogenicity of Fusarium oxysporum f. sp. melonis races from different areas of Italy. J. Phytopathol. 163:73-83.

Ma, C., Jian, G. L., and Zheng, C. L. 2002. The advances in cotton breeding resistance to Fusarium and Verticillium wilts in China during past fifty years. Sci. Agric. Sin. 35:508-513.

Mishra, R. K., Pandey, B. K., Singh, V., Mathew, A. J., Pathak, N., and Zeeshan, M. 2013. Molecular detection and genotyping of Fusarium oxysporum f. sp. psidii isolates from different agro-ecological regions of India. J. Microbiol. 51:405-412.

Mueller, U. G., and Wolfenbarger, L. L. 1999. AFLP genotyping and fingerprinting. Trends Ecol. Evol. 14:389-394.

Nei, M. 1978. Estimation of average heterozygosity and genetic distance from a small number of individuals. Genetics 89:583-590.

Nirenberg, H., Ibrahim, G., and Michail, S. 1994. Race identity of three isolates of Fusarium oxysporum Schlecht. f. sp. vasinfectum (Atk.) Snyd. \& Hans. from Egypt and the Sudan. J. Plant Dis. Prot. 101:594-597.

Silva, F. P. D., Vechiato, M. H., and Harakava, R. 2014. EF-1 $\alpha$ gene and IGS rDNA sequencing of Fusarium oxysporum f. sp. vasinfectum and $F$. oxysporum f. sp. phaseoli reveals polyphyletic origin of strains. Trop. Plant Pathol 39:64-73

Skovgaard, K., Nirenberg, H. I., O’Donnell, K., and Rosendahl, S. 2001. Evolution of Fusarium oxysporum f. sp. vasinfectum races inferred from multigene genealogies. Phytopathology 91:1231-1237.

Sun, W. J., Jian, G. L., and Chen, Q. Y. 1999. Study on monitoring of physiological race of cotton Fusarium wilt in China. Sci. Agric. Sin. 32:51-57.

Ulloa, M., Hutmacher, R. B., Roberts, P. A., Wright, S. D., Nichols, R. L., and Davis, R. M. 2013. Inheritance and QTL mapping of Fusarium wilt race 4 resistance in cotton. Theor. Appl. Genet. 126:1405-1418.

Wang, B., Brubaker, C. L., Summerell, B. A., Thrall, P. H., and Burdon, J. J. 2010 Local origin of two vegetative compatibility groups of Fusarium oxysporum f. sp. vasinfectum in Australia. Evol. Appl. 3:505-524.

Wang, B., Brubaker, C. L., Tate, W., Woods, M. J., Matheson, B. A., and Burdon, J. J. 2006. Genetic variation and population structure of Fusarium oxysporum f. sp. vasinfectum in Australia. Plant Pathol. 55:746-755.

Zambounis, A., Paplomatas, E., and Tsaftaris, A. S. 2007. Intergenic spacer-RFLP analysis and direct quantification of Australian Fusarium oxysporum f. sp. vasinfectum isolates from soil and infected cotton tissues. Plant Dis. 91: $1564-1573$. 